\title{
Ethics in Higher Education and Problem-Based Learning
}

\author{
Anna Carolina Moreno ${ }^{1}$ \\ ${ }^{1}$ University of Porto, Portugal \\ Correspondence: Anna Carolina Moreno, University of Porto, Portugal.
}

Received: February 9, 2018

Accepted: March 1, 2018

Online Published: March 5, 2018

doi:10.20849/aes.v3i1.328

URL: https://doi.org/10.20849/aes.v3i1.328

\begin{abstract}
Based on the daily problematics of the current globalized world, this article aims to reiterate the relevance of Ethics' studies in higher education. The analysis utilises the Problem-Based Learning (PBL) concept and the Kantian reflections on education to offer a constructive way to stimulate students' moral growth. The study begins with an introduction of its significance, then it considers the materials studied and the methodology used. Through the collection of bibliographical data, a descriptive approach to Howard Barrows' instruction method and the Kantian thought is given. Afterwards, the paper explains the harmonization between both, showing how Ethics can and should be debated during professional training. It also explains the role of the PBL in this process, concluding that both are the perfect combination for allowing not only the students but also the tutors, to develop their individual common sense and to better adapt to unexpected challenges.
\end{abstract}

Keywords: Kant, problem-based learning, ethics, education

\section{Introduction}

It can be stated that "'Education' has notions such as 'improvement', 'betterment', and 'the passing on of what is worthwhile' built into it. That education must involve something of ethical value is, therefore, a matter of logical necessity." (Peters, 2015, p. 91)

But the question is: Why is it a necessity? The answer is revealed in these two definitions found in Oxford Dictionaries: 1. Ethics is "the branch of knowledge that deals with moral principles", and 2. an ethical behavior is defined by "the moral correctness of specified conduct".

This means that Education must relate to ethical studies in order to enable students to make moral judgements and to feel empathy for their fellow citizens. Nowadays, even though there is the opportunity for a basic encounter with Ethics in schools and universities, the individual critical thought is not developed as a result. This means that the ethical theory may be taught, but its practice is put to one side.

The immediate necessity is to reverse this situation by focusing on the needs of high educational students, given that they are the ones who are going to enter society as contributors to its growth and functioning. They must be prepared to handle cultural, political, religious, and ethnical differences in an ethical and understanding way, being able to think and act outside the box.

Bearing this in mind, this article uses the concept of Problem-Based Learning (PBL) and the Kantian reflections on Ethics and Educations to propose a constructive way to stimulate students' moral growth, preparing them for the globalized world.

\section{Materials Studied}

This article is aimed at reaffirming the relevance of ethical studies for the development of higher education student's critical thought. Thus, the work of several scholars from various areas of knowledge was used to better analyze the factors that are pertinent to the progress of the human critical ability. The focus on Kant and PBL is based on the relevance given to moral growth by one, and the freedom of thought allowed by the other. The analysis used literary sources-from books to papers-from Philosophy, Pedagogy, Psychology, and Medicine. The main authors used were Immanuel Kant (1900; 2007), Rosa Gomes et al. (2016), Richard S. Peters (2015), and Malcolm Parker (1995). 


\section{Methodology}

The method is a qualitative with hermeneutic-phenomenological approach, based on the research of literary endorsement. The study was divided into five parts: Firstly, establishing the relevance of the paper; secondly, refining the scope of the survey; thirdly, conceptualizing Ethics and the Problem-Based Learning; fourthly, highlighting the relation between Kant and Education, as well as relating the PBL to human moral development; fifthly, proving the relation between Ethics and PBL, which lead to the conclusion of this paper (Alves, P. C.; Rabelo, M. C.; Souza, I. M., 2014).

\section{Discussion}

\subsection{Problem-Based Learning (PBL)}

Howard Barrows, in the 1960s, invented an innovative study method called Problem-Based Learning, or PBL, which consists of reducing the difference between professional training and its practice, adapting the capabilities acquired by higher education students to the transdisciplinary reality that awaits them (Barrows, 1986).

The pedagogical basis of this teaching method requires the active participation of the students in their learning. Realistic problems are proposed to them, and each student, through personal research, attempts to provide ways to resolve them, applying different disciplines in their method. In the interests of student's development, a group discussion is encouraged to bring to light the varied knowledge acquired by the students, therefore the possibility of experiencing professional practice is enabled (Barrows, 1986) (Schmidt; Rotgans.; \& Yew, 2011).

This discussion is carried out with support of the tutor, helping the student understand their learning, organize their research strategically, and reason in a more flexible way. Thus, the role of the tutor is essential in the dynamics and orientation of the educational process, guiding the student towards a consideration of the context in which each existing situation may occur in a flexible and appropriate way, so they can find the best approach to it. Therefore, the tutorial sessions serve not only for the acquisition of professional skills but also for the personal development of young adults, as they allow them to hear other points of view, other values, and ideals (Botti; \& Rego, 2008).

This cognitive and emotional awareness arises from a specific area of dialogue, tolerance, and cooperation of the PBL, since

The PBL favors the development of concepts, gives a global vision to both students and teachers of how concepts are constructed in science, implies the experience of challenges and difficulties for the students, potentiates the production of knowledge and know-how, not their justification, and expands both basic and complex skills (critical thinking and decision making). (Gomes, Brito, \& Varela, 2016, p. 47)

Thus, a habit of reasoning and researching is created, as well as allowing the student to understand the existence of several answers to an issue and sympathize with this fact.

\subsection{Ethics in Kant}

Immanuel Kant affirms in his work "Groundwork of the Metaphysic of Morals" (2007) that reason has two essential structures: sensibility and understanding. The latter allows insight into everything that is unnatural to man. The former ties the idea of "time and space" to what exists. These concepts have limiting conflicts, because such generalizations are not "palpable" to human rationality, allowing paradoxes to be valid for the same theme.

Another characteristic of reason is its coexistence with irrationality. This means that the human being is in constant conflict between its instincts and intelligence, dividing reality into formal and material. The result of the first is logic, and the second generates both the concepts of "what is" (nature) and "what should be" (man). Ethics deals with either, with the aim of using reason in the search for refining individual thoughts and actions (Kant, 2007).

From these points, Kant idealizes a universal ethic based on goodwill, which comes from reason and focuses on the duty of the person. Based on human rationality, the consequence of this train of thought is that every existing man can have the same ethic, even if the ethical principle is not developed. Defining "duty" is more complex, for it can be divided into an action according to duty (for benefits) and action for duty (aiming for itself). Of these, only the latter is prescribed by rationality and is therefore subject to morality (Kant, 2007).

Thus, the principles that generate such action need to be universal, constituting categorical imperatives. This means that rational subjective principles can be subject to generalization, being any acceptable action when it has a purpose for them. The means acting in the best way possible is also defined through those imperatives, 
considering the subjective ends (they are of a particular type and are worth the experimentation) and objectives (they are universal) as being harmonized by the moral practice (Kant, 2007) (Walker, 1999).

However, for such universalization to occur, some moral laws become necessary. These must not only be very well founded but must also be equated with natural laws, presenting sufficient coercive force for ethical action to be part of the human being (Kant, 2007).

It is only after guaranteeing the autonomy of the will to follow categorical imperatives using its reason, that man finds his dignity, his capacity for self-regulation. As a result, homo sapiens sapiens become free in the empirical world to make their choices with the aim of reaching the moral end and are therefore guided by rational impositions on their will in the transcendental world (Kant, 2007).

\subsection{Kant and Education}

In the work titled "On Education" (1900), the philosopher defends the idea that man's characteristics are formed through education, which is divided into these essential points: nourishing as an act of limiting human action; the discipline to restrict individual animal nature, facilitating the capability to fit into society and not harm itself; the culture, informing and instructing in order to develop personal skills; the prudence to act within the social contract; and moral training, which consists of teaching the individual to ensure positive outcomes of their actions; that is, to have goals approved and shared by all.

As a result, the ability to improve one's morality is accepted as being the consequence of the experience and understanding of common sense, but this results in the negligence of morality during the construction of the human being. Kant states that man is born with tendencies to do what is good, however, he does not have the reasoning that allows him to reach his initial goal, particularly as he can be easily corrupted. That is why it is necessary to guide him (Kant, 1900).

The empowerment of this practical education is essential in enabling the individual to live freely. This means that personal character is formed by maintaining a connection between individuality and the social role of everyone. Therefore, it is not sufficient for learners to only have contact with basic school subjects. Attention should be given to the teaching of practical questions that require critical thinking and wisdom. Kant reflects on the relevance of the teacher in the development of the human being, differentiating between private teachers and tutors, since the former prepare the youngsters for school and the latter equip them for life, guiding and directing them (Kant, 1900).

\subsection{Ethics' Relevance on Education and the Role of Problem-Based Learning in This Scenario}

The current globalized context connects all human beings, regardless of their nationality, ethnicity, culture, profession, or belief. As Lawrence Blum (2016) stated,

Multiculturalism involves an understanding, appreciation, and valuing of one's own culture, and an informed respect and curiosity about the ethnic cultures of others. It involves a valuing of other cultures, not in a sense of approving of all aspects of those cultures, but of attempting to see how a given culture can express value to its own members [my emphasis]. (May; Delston; Blum; Nussbaum; Mill; O’Neil et al, 2016, p. $\mathrm{xv})$

Thanks to this multicultural contact, it is possible to observe that the ethical challenges do not demonstrate a universal resolution, it varies according to the previously mentioned factors (Vieira, A.; \& Vieira R., 2016). This means that the individual, as a social being and diverging from the Kantian belief in the universality of Ethics, must be prepared to conform to a wide range of decision-making habits other than his own, through aesthetics experience and dialog, so that it is able to not only recognize the singularity of his companions but also avoid ethical consequences that come from rationalism and universalism (Hermann, 2014). The ability to analyze conflicts in an interdisciplinary way is also an essential tool for its growth.

In order to do this, a multidisciplinary aid is required during individual training to explain that the complexity of today's affairs requires, as briefly observed by Poh et al. (2014), the recognition of the strengths and weaknesses of the subject; as well as those of his companions in his professional and gregarious life. Through such instruction, it is possible to stimulate active interpersonal collaboration in the identification, analysis, and resolution of some concerns and issues; thus providing a better understanding of the situation given the varied perspectives stated. That is, whilst studying in higher education, the student should have contact with colleagues within, and outside, their subject; because their different pasts, preferences, cultures, and values will provide valuable material in the discussion of key cases, thereby developing general ethical sensitivity. 
Parker (1995) stated that Problem-Based Learning functions in a way that allows contact with Ethics, even though tutors do not have experience in this field, given that we all have our beliefs and the relevant aspect is allowing the interpersonal exchange of experiences. The PBL enables such an environment by making use of dilemmas; recognizing doubt and uncertainty; allowing personal understanding of your own point of view during group meetings; and encouraging the students to learn more. Therefore, presenting cases that not only involve specific skills of an academic training, but also those of Ethics, will allow students to develop the critical thinking necessary for good social interaction and an advanced ability to solve problems in a constructive way, by listening to the other and considering their ideals (Schmidt; Rotgans; \& Yew, 2011).

In this way, an efficient facilitator is needed to guide pupils when exploring the setback they've studied, helping them identify the knowledge and strategies needed to solve it (Kurtz; \& Starbird, 2016, p. 921); whilst also stimulating the expression of their opinions. By instigating such discussion in a friendly situation, the participants gradually put old prejudices aside, seeking new worldviews.

Therefore, the tutor should not necessarily have a past of ethical studies but should be able to encourage the students to position themselves actively in the demonstration of both their research and their principles. Here, the teacher has the role of guiding, as described by Kant.

\section{Conclusion}

Two of the Kantian morality laws claim that both the development of personal abilities and the possibility given to everyone to progress with their individual faculties (thus optimizing social coexistence) are essential not only in promoting general well-being but also in human nature. One concludes that it is through a good ethical basis that the human becomes a good social being.

To aid the development of this characteristic, a good tutor is needed to encourage young people to think for themselves, considering the scenarios which they will experience whilst adults. In other words, since the individuals are preparing themselves for their professional practice, it is indispensable that knowledge building is guided through multidisciplinary and collective critical thinking, considering the socio-historical and cultural context of the ethical challenges they are going to confront on a daily basis.

In order to meet these requirements throughout the higher education programs, the production of professional competence (Sá, P., \& Paixão, F., 2013) guided by the Kantian Ethics requires a pedagogical method capable of enabling the contact with the different, the professional practice and the mediation of a tutor, so that the students are able to not only learn how to learn and how to do but also to learn how to be and how to live together (Delors, 2013).

The PBL includes the Kantian ideal of a tutor who guides students in their discoveries, not simply passing on knowledge, but instigating them to research and learn on their own (Bate; Duvivier; Hommes; \& Taylor, 2014). This method's design meets the Kantian standards of Education, and the adoption of PBL under this prism will provide students with the tools needed to solve daily problems ethically. They will be able to reason expertly; to consider the vast possibilities, values, and opinions existing; and to resolve conflicts in a constructive way. Ethics taught through Problem-Based Learning is a cornerstone for the training of professionals who, as a result, are better prepared to enter the job market, making them even more insightful and flexible when responding to dilemmas.

\section{References}

Alves, P.C., Rabelo, M.C., \& Souza, I.M. (2014). Hermenêutica-fenomenológica e compreensão nas ciências sociais. Revista Sociedade e Estado, 29(1), 181-198. https://doi.org/10.1590/S0102-69922014000100010

Barrows, H.S. (1986). A taxonomy of problem: based learning methods. Medical Education, 20(6), 481-486. https://doi.org/10.1111/j.1365-2923.1986.tb01386.x

Bate, E., Duvivier, R., Hommes, J., \& Taylor, D.C.M. (2014). Problem-based learning (PBL): Getting the most out of your students-Their roles and responsibilities. AMEE Guide-Medical Teacher, 36(84), iss. 1.

Botti, S.H., \& Rego, S. (2008). Preceptor, Supervisor, Tutor and Mentor: What are Their Roles? Revista Brasileira de Educação Médica, 32(3), 263-73.

Delors, J. (2013). The treasure within: Learning to know, learning to do, learning to live together, and learning to be. What is the value of that treasure 15 years after its publication?. International Review of Education, 59(3), 319. https://doi.org/10.1007/s11159-013-9350-8

English Oxford Dictionairies [Internet]. Oxford: University of Oxford. Ethics. Retrieved February 8, 2018, from https://en.oxforddictionaries.com/definition/ethics 
Gomes, R.M., Brito, E., \& Varela, A. (2016). Intervenção na Formação no Ensino Superior: A Aprendizagem Baseada em Problemas (PBL). Interacções, (42), 44-57.

Hermann, N. (2014). Ética \& Educação: Outra sensibilidade. (1st ed.). Belo Horizonte: Editora Autentica.

Kant, I. (1900). On Education. Boston: D.C. Heath \& CO.

Kant, I. (2007). Fundamentação da metafisicica dos costumes (1st ed.). Lisboa: Edições 70.

Kurtz, M.J., \& Starbird, L.E. (2016). Interprofessional Clinical Ethics Education: The Promise of Cross-Disciplinary Problem-Based Learning. AMA Journal of Ethics, 18(9), 917-924. https://doi.org/10.1001/journalofethics.2016.18.9.nlit1-1609

Blum, L.A., Nussbaum, M., Mill, J.S., O’Neil, Onora, et al.. (2016). Applied Ethics:a multicultural approach (6th ed.), May, Larry, \& Delston, Jill B. (Eds.). New York: Routledge.

Parker, M. (1995). Autonomy, problem-based learning, and the teaching of medical ethics. Journal of Medical Ethics, (21), 305-310. https://doi.org/10.1136/jme.21.5.305

Peters, R.S. (2015). Ethics and Education. New York: Routledge Revivals.

Poh, P.S.H. et al.. (2014). International Multidisciplinary Learning: An Account of a Collaborative Effort Among Three Higher Education Institutions. International Conference e-Learning.

Sá, P., \& Paixão, F. (2013). Contributos para a clarificação do conceito de competência numa perspectiva integrada e sistémica. Revista Portuguesa de Educação, 26(1), 87-114. https://doi.org/10.21814/rpe.2985

Schmidt, H.G., Rotgans, J.I., \& Yew, E.H. (2011). The process of problem-based learning: what works and why. Medical Education, 45(8), 792-806. https://doi.org/10.1111/j.1365-2923.2011.04035.x

Vieira, A.M., \& Vieira, R. (2016). Ética(s) e Educação Social. Pedagogia Social, Mediação Intercultural e (Trans)formações. Porto: Profedições, 80-90.

Walker, R. (1999). Kant: Kant e a lei moral. São Paulo: Editora UNESP.

\section{Copyrights}

Copyright for this article is retained by the author(s), with first publication rights granted to the journal.

This is an open-access article distributed under the terms and conditions of the Creative Commons Attribution license (http://creativecommons.org/licenses/by/4.0/). 